Wahyudin, A. · Y. Yuwariah · F.Y. Wicaksono $\cdot$ R.A.G. Bajri

\title{
Respons jagung (Zea mays 1.) akibat jarak tanam pada sistem tanam legowo (2:1) dan berbagai dosis pupuk nitrogen pada tanah inceptisol Jatinangor
}

\section{Maize response due to legowo planting system (2:1) and various doses of nitrogen fertilizers in inceptisol soil of Jatinangor}

Diterima : 11 Desember 2017/Disetujui : 18 Desember 2017 / Dipublikasikan : 30 Desember 2017

CDepartment of Crop Science, Padjadjaran University

\begin{abstract}
In Indonesia maize is the second source of carbohydrate after rice. Also, maize could use for animal feed and other purposes. This research is to obtain the best growth and yield of Pertiwi 3 Hybrid after treatments application, legowo planting system (2:1) and various dosages of $\mathrm{N}$ fertilizers. The research was started from November 2016 to March 2017 in Jatinangor. The experimental design used Factorial Randomized Block design with two different treatments and it was repeated three times. The treatment consists of the combining of two factors. The first factor is a variety of $\mathrm{N}$ dosage which are $200 \mathrm{~kg} / \mathrm{ha} \quad(2,25 \mathrm{~g} /$ hole $)$, $300 \mathrm{~kg} / \mathrm{ha}(3,75 \mathrm{~g} /$ hole $)$ and $400 \mathrm{~kg} / \mathrm{ha}(5 \mathrm{~g} /$ hole $)$. The second factor was three legowo planting system, $75 \mathrm{~cm} \times 25 \mathrm{~cm} \times 25 \mathrm{~cm}, 75 \mathrm{~cm} \times 25 \mathrm{~cm} \times$ $25 \mathrm{~cm}$ and $75 \mathrm{~cm} \times 35 \mathrm{~cm} \times 35 \mathrm{~cm}$. The result showed a positive interaction between the treatment of legowo planting system and application of $\mathrm{N}$ fertilizers on the Leaf Area Index of maize. The treatment shows a significant difference on leaf area index and weight of dried corn kernel per plot. The best legowo 2:1 treatment was showed under treated $75 \mathrm{~cm} \times 25 \mathrm{~cm} \times 25 \mathrm{~cm}$ legowo planting system on yield, $12264.00 \mathrm{~g} / \mathrm{plot}$ or equal to 11.68 ton/ha and the dosage $400 \mathrm{~kg} / \mathrm{ha}$ of $\mathrm{N}$ fertilizers showed the best yield, $11036.27 \mathrm{~g} /$ plot or equal to 10.05 ton/hectare.
\end{abstract}

Keywords: Corn, Legowo planting system (2:1), $\mathrm{N}$ fertilizers

Sari Di Indonesia jagung menjadi sumber

\footnotetext{
Dikomunikasikan oleh Aep Wawan Irwan

Wahyudin, $\mathrm{A}^{1}$. Y. Yuwariah ${ }^{1}$ · F.Y. Wicaksono ${ }^{1}$. R.A.G. Bajri $^{2}$

1Staf Pengajar Fakultas Pertanian universitas Padjadjaran,

${ }^{2}$ Alumni Fakultas Pertanian Universitas Padjadjaran.

Korespondensi: agus.wahyudin@unpad.ac.id
}

karbohidrat kedua setelah padi. Selain sebagai sumber kebutuhan pangan jagung juga dapat digunakan sebagai sumber pakan ternak dan bahan baku industri.Penelitian ini bertujuan untuk mengamatiinteraksi sistem tanam legowo (2:1) dengan pupuk $\mathrm{N}$ yang menghasilkan pertumbuhan dan hasil terbaik pada tanaman jagung (Zea mays L.) Hibrida Pertiwi 3, di Jatinangor mulai bulan November 2016 sampai Maret 2017. Percobaan menggunakan Rancangan Acak Kelompok Pola Faktorial. Perlakuan terdiri dari dua faktor, masing-masing faktor terdiri dari tiga taraf dan diulang tiga kali. Faktor pertama adalah sistem tanam legowo (2:1) dengan menggunakan jarak tanam yang terdiri dari tiga taraf yaitu $75 \mathrm{~cm}$ x $25 \mathrm{~cm} \times 25 \mathrm{~cm}, 75 \mathrm{~cm} \times 30 \mathrm{~cm} \times 30 \mathrm{~cm}$ dan $75 \mathrm{~cm}$ $\times 35 \mathrm{~cm} \times 35 \mathrm{~cm}$. Faktor kedua adalah dosis pupuk $\mathrm{N}$ terdiri dari tiga taraf, yaitu $200 \mathrm{~kg} / \mathrm{ha}(2,25$ $\mathrm{g} /$ lubang), $300 \mathrm{~kg} / \mathrm{ha}(3,75 \mathrm{~g} /$ lubang$)$ dan 400 $\mathrm{kg} / \mathrm{ha}$ (5 g/lubang).Hasil percobaan menunjukkan bahwa terdapat interaksi antara jarak tanam legowo $2: 1$ denganpemberian pupuk $\mathrm{N}$ terhadap Indeks Luas Daun tanaman jagung. Jarak tanam legowo $2: 1$ memberikan hasil terbaik yaitu pada jarak tanam $75 \mathrm{~cm} \times 25 \mathrm{~cm} \times 25 \mathrm{~cm}$ dengan hasil (12264.00 g/petak atau 11,68 ton/ha) dan dosis pupuk N $400 \mathrm{~kg} / \mathrm{ha}$ dengan hasil (11036.27 $\mathrm{g} /$ petak atau 10.05 ton/ha) terhadap bobot biji pipilan kering per petak dan per hektar.

Kata kunci: Jagung, Sistem Tanam Legowo (2:1), Dosis Pupuk N

\section{Pendahuluan}

Tanaman Jagung merupakan salah satu komoditas pangan di Indonesia yang memiliki nilai ekonomi, akan tetapi memiliki tingkat produksi yang fluktuatif tiap tahunnya, serta 
dengan tingkat peningkatan produksi yang cukup rendah tiap tahun. Hal ini terlihat dari hasil produksi jagung tahun 2014 sebanyak 19,033 juta ton atau mengalami peningkatan sebanyak 0,52 juta ton dibandingkan tahun 2013 sedangkan untuk ketersediaan dari tanaman jagung itu pun mengalami kenaikan serta penurunan non signifikan terlihat dari data ketersediaan jagung 2010 sebanyak 16,222 juta ton, 2011 sebanyak 15,612 juta ton, 2012 sebanyak 17,169 juta ton, 2013 sebanyak 16,391 juta ton dan 2014 sebanyak 16,853 juta ton (BKP 2015). Hal tersebut dapat menjadi acuan bagi kita untuk meningkatkan budidaya tanaman jagung, melihat peranan tanaman jagung cukup besar serta ketersidaan tanaman jagung yang kurang stabil tiap tahunnya. Kebutuhan jagung pada tahun 2016 diproyeksikan sebesar 13,8 juta ton dimana kebutuhan akan jagung ini dibagi kedalam dua kebutuhan yaitu untuk pangan yang mencapai 8,6 juta ton dan pakan 5,2 juta ton. Kebutuhan jagung pada tahun 2016 menigkat dibandingan kan 2015 yang hanya 13,1 juta ton. Untuk kebutuhan pakan mencapai 8,3 juta ton dan untuk pangan mencapai 4,1 juta ton (Kementerian Perindustrian, 2016).

Upaya yang dapat dilakukan guna meningkatkan produksi tanaman jagung di Indonesia salah satunya dengan cara menanam benih varietas unggul, seperti dengan menggunakan jagung Hibrida Pertiwi 3. Keunggulan dari jagung Hibrida Pertiwi 3 adalah memiliki ketahanan terhadap cekaman bulai, karat daun dan hawar serta memiliki ratarata hasil 9,64ton/ha dan memiliki potensi hasil yang tinggi yaitu 13,74 ton/ha pipilan kering (Kementrian Pertanian, 2013). Varietas jagung berumur genjah sangat diperlukan oleh banyak petani guna menyesuaikan pola tanam serta ketersediaan air, namun varietas jagung berumur genjah yang beredar saat ini umumnya merupakan varietas lokal dan komposit yang memiliki potensi hasil rendah sehingga perlu dibuat varietas hibridanya (Sinartani, 2011).

Penggunaan varietas hibrida tentunya perlu diikuti dengan upaya yang lainnya yaitu dengan pengaturan sistem jarak tanam dan proses pemupukan yang tepat pada tanaman jagung agar memperoleh hasil yang optimal, setelah mengetahui kelebihan dari penggunaan varietas hibrida Pertiwi 3 tanaman jagung, maka perlu dilakukan upaya penerapan inovasi teknologi yang optimal untuk mendapatkan hasil yang tinggi, yaitu berupa pengaturan sistem tanam yang tepat serta efektif bagi tanaman jagung.

Pengaturan sistem tanam pada suatu lahan pertanian merupakan salah satu cara yang memiliki pengaruh terhadap hasil dari tanaman, pengaturan sistem jarak tanam berkaitan terhadap kepadatan suatu populasi di area lahan, proses penerimaan cahaya matahari yang tentunya berkaitan dengan proses fotosintesis tanaman dan persaingan hara antar tanaman. Penerapan jarak tanam yang efektif pada dasarnya bertujuan untuk memberikan kemungkinan tanaman agar tumbuh dengan baik tanpa mengalami banyak persaingan dalam hal ketersediaan air, unsur-unsur hara, dan cahaya matahari secara optimal untuk proses fotosintesis (Ikhwani $d k k, 2013$ ). Proses budidaya jagung dengan sistem tanam legowo merupakan suatu teknologi inovasi yang dapat mengatasi permasalahan peningkatan produksi jagung di Indonesia, pemenuhan kebutuhan jagung yang semakin bertambah setiap tahun, serta memiliki banyak keuntungan bagi tanaman jagung itu sendiri.

Menurut Stalcup (2008),penanaman sistem tanam satu baris merupakan hal umum, oleh karena itu perlu diterapkan pertanaman sistem dua baris karena mampu memberikan hasil lebih tinggi.Jagung yang ditanam dengan sistem tanam baris kembar memiliki potensi akses lebih besar untuk penyerapan air, penerimaan cahaya matahari, penyerapan unsur hara dan meningkatkan kemampuan untuk mengatasi kondisi stres pada tanaman jagung (Monsanto, 2009).

Pemberian pupuk merupakan salah satu faktor produksi pertanian yang sangat penting selain ketersediaan lahan, tenaga kerja dan modal, pemupukan yang berimbang memegang peranan penting dalam upaya meningkatkan hasil tanaman jagung serta rekomendasi pemupukan harus dibuat secara rasional dan berimbang berdasarkan kebutuhan hara pada tanah dan kebutuhan tanaman akan unsur hara sehingga meningkatkan efektifitas serta efisiensi penggunaan pupuk dan produksi tanpa membuat kerusakan lingkungan akibat pemupukan yang terlalu berlebihan (Tuherkih dan Sipahutar, 2008).

Unsur hara $\mathrm{N}$ merupakan unsur hara makro esensial yang ketersediaannya dapat memberikan pengaruh nyata jika diberikan pada tanah inceptisol. Unsur hara $\mathrm{N}$ bersifat mobil dan mengakibatkan mudah hilang, apalagi jika dengan pemberian yang kurang tepat, bahkan 
hampir semua tanman yang ditanam baik di lahan sawah maupun lahan kering sangat membutuhkan unsure hara N (Kasno, 2010)

Nitrogen (N) merupakan unsur hara penting yang sangat dibutuhkan oleh tanaman jagung untuk proses pertumbuhan. Selama proses pertumbuhan sampai dengan proses pematangan biji nitrogen terus menerus diserap oleh tanaman, sehingga tanaman jagung sangat menghendaki dan membutuhkan ketersediaan unsur $\mathrm{N}$ secara terus menerus pada semua stadia pertumbuhan sampai pembentukan biji. Pemberian dosis pupuk yang tepat selama pertumbuhan tanaman jagung dapat meningkatkan hasil jagung (Saragih, dkk. 2013)

\section{Bahan dan Metode}

Percobaan ini dilaksanakan di Kebun Percobaan Ciparanje Fakultas Pertanian Universitas Padjadjaran, Jatinangor, Kabupaten Sumedang, Jawa Barat dengan ketinggian tempat \pm 750 meter di atas permukaan laut, dengan ordo tanah Inseptisols, dan tipe curah hujan C3 menurut Oldeman (1975). Waktu pelaksanaan percobaan dimulai pada bulan November 2016 hingga Maret 2017. Rancangan percobaan yang digunakan adalah Rancangan Acak Kelompok (RAK) Faktorial, yang terdiri atas 2 faktor dengan 3 ulangan dan terdiri dari sembilan perlakuan $(9 \times 3)$ untuk tiap perlakuan, sehingga terdapat 27 petak perlakuan. Perlakuan terdiri atas Jarak Tanam Legowo $2: 1$ yaitu $\mathrm{j}_{1}(75 \times 25 \times$ $25 \mathrm{~cm}), \mathrm{j}_{2}(75 \times 30 \times 30 \mathrm{~cm})$, dan j $3(75 \times 35 \times 35$ $\mathrm{cm})$. Perlakuan pupuk N yaitu $\mathrm{p}_{1} 200 \mathrm{~kg} / \mathrm{ha}, \mathrm{p}_{2}$ $300 \mathrm{~kg} / \mathrm{ha}$, dan $\mathrm{p}_{3} 400 \mathrm{~kg} / \mathrm{ha}$. Aplikasi perlakuan jarak tanam dilakukan saat penanaman dan perlakuan pemberian pupuk $\mathrm{N}$ dilakukan dua kali yaitu pada saat 2 MST dan 5 MST sedangkan untuk pupuk $\mathrm{P}$ dan K diberikan pada saat awal tanam. Benih Jagung yang digunakan adalah Hibrida Pertiwi-3 tahan bulai, karat daun dan hawar daun dengan cara ditugal sedalam $5 \mathrm{~cm}$.

Pengamatan yang dilakukan terdiri atas pengamatan penunjang (analisis tanah sebelum percobaan, pengamatan cuaca, tingkat serangan hama, penyakit, dan gulma yang tumbuh. Pengamatan utama meliputi komponen pertumbuhan tinggi tanaman diukur pada saat tanaman berumur 4 MST 6 MST 8 MST, indeks luas daun diukur pada saat tanaman berumur 10 MST dengan metode Gravimetri. Pengamatan komponen hasil panjang tongkol $(\mathrm{cm})$, diamter tongkol $(\mathrm{cm})$, jumlah baris per tongkol, jumlah biji per tongkol. Pengamatan hasil meliputi bobot 100 biji (g), bobot biji pipilan kering per tanaman $(\mathrm{g})$, bobot biji pipilan kering per petak (g), hasil (ton/ha), indeks panen. Pengamatan pertumbuhan, komponen hasil, dan hasil dilakukan terhadap sampel tanaman yang diambil $10 \%$ dari populasi tanaman dengan cara mengambil sampel dari tanaman pada bagian tengah setiap petak perlakuan.

\section{Hasil dan Pembahasan}

Selama percobaan berlangsung, jumlah curah hujan berkisar antara 109-432 $\mathrm{mm} /$ bulan sementara curah hujan yang ideal untuk tanaman jagung yaitu sekitar 100-200 mm/ bulan (Warisno, 2007). Kelembaban nisbi selama percobaan berkisar antara 89-90,2 \% dan suhu selama percobaan berkisar antara $23,1-27,7{ }^{\circ} \mathrm{C}$. Kelembaban dan suhu tersebut sudah memenuhi syarat pertumbuhan tanaman jagung yaitu kelembaban berkisar antara 80-90\% (Balitsereal, 2008) dan suhu berkisar $21-30{ }^{\circ} \mathrm{C}$ (Warisno, 2007). Tanah Inceptisols pada lahan percobaan mempunyai tekstur liat berdebu dan mempunyai $\mathrm{pH}$ sebesar 6,32. Derajat keasaman tanah $(\mathrm{pH})$ yang paling baik untuk tanaman jagung adalah 5,0-7,0 dan tanah yang baik untuk pertumbuhan jagung adalah tanah dengan tekstur lempung/liat berdebu (Warisno, 2007).Hasil pengamatan menunjukkan terdapat beberapa serangan hama, penyakit dan terdapat gulma yang menyerang tanaman jagung pada saat dilakukannya penelitian, tetapi serangan gulma tidak menghambat pertumbuhan tanaman. Hama yang menyerang pada tanaman jagung adalah kutu daun Rhopaloshipum maidis (Hemiptera: Aphididae), belalang (Oxia chinensis), ulat grayak (Spodoptera litura) serta penyakit bulai dan gulma yang menyerang adalah rumput teki (Cyperus rotundus L.).

Pengamatan utama meliputi komponen pertumbuhan berupa tinggi tanaman dan indeks luas daun, komponen hasil dan hasil. Pengamatan tinggi tanaman disajikan dalam Tabel 1. Tidak terdapat interaksi antara jarak tanam legowo $2: 1$ dan pupuk $N$ terhadap tinggi tanaman pada tanaman jagung hibrida Pertiwi 3.

Salah satu faktor yang mempengaruhi pertumbuhan pada tanaman adalah ketersediaan unsur hara yang terdapat dalam tanah. Menurut 
Setyamidjadja (1986) Nitrogen memiliki peranan untuk merangsang pertumbuhan vegetatif yaitu menambah tinggi tanaman.Pada percobaan ini tinggi tanaman jagung sampai 8 MST yaitu $185,67 \mathrm{~cm}$ pada efek mandiri pemberian dosis pupuk N $400 \mathrm{~kg} / \mathrm{ha}$. Tinggi tanaman jagung pada penelitian ini sudah sesuai dengan deskripsi jagung hibrida Pertiwi 3 hal ini dikarenakan pasokan Nitrogen dalam tanah dan yang diberikan mampu merangsang pertumbuhan vegetatif dari tanaman jagung.

Tabel 1. Respons Perlakuan Jarak Tanam Legowo 2 : 1 dan Pupuk $N$ Terhadap Tinggi Tanaman Jagung Hibrida Pertiwi 3.

\begin{tabular}{lccc}
\hline \multicolumn{1}{c}{ Perlakuan } & \multicolumn{3}{c}{ Tinggi Tanaman $(\mathbf{c m})$} \\
& 4 MST & 6 MST & 8 MST \\
\hline Jarak Tanam Legowo $\mathbf{2 : 1}$ & & \\
j1 $(75 \times 25 \times 25 \mathrm{~cm})$ & $70,22 \mathrm{a}$ & $130,16 \mathrm{a}$ & $186,40 \mathrm{a}$ \\
$\mathrm{j}_{2}(75 \times 30 \times 30 \mathrm{~cm})$ & $65,42 \mathrm{a}$ & $121,85 \mathrm{a}$ & $165,71 \mathrm{a}$ \\
$\mathrm{j}_{3}(75 \times 35 \times 35 \mathrm{~cm})$ & $70,12 \mathrm{a}$ & $127,62 \mathrm{a}$ & $175,01 \mathrm{a}$ \\
\hline Pupuk N & & & \\
$\mathrm{p}_{1} 200 \mathrm{~kg} / \mathrm{ha}$ & $65,84 \mathrm{a}$ & $119,57 \mathrm{a}$ & $165,35 \mathrm{a}$ \\
$\mathrm{p}_{2} 300 \mathrm{~kg} / \mathrm{ha}$ & $67,91 \mathrm{a}$ & $125,09 \mathrm{a}$ & $176,10 \mathrm{a}$ \\
$\mathrm{p}_{3} 400 \mathrm{~kg} / \mathrm{ha}$ & $71,99 \mathrm{a}$ & $134,97 \mathrm{a}$ & $185,67 \mathrm{a}$ \\
\hline
\end{tabular}

Keterangan : Angka rata-rata pada tiap kolom yang ditandai huruf yang sama menunjukkan tidak berbeda nyata menurut uji Jarak Berganda Duncan Taraf $5 \%$.

Pengamatan komponen pertumbuhan indeks luas daun disajikan pada Tabel 2 . Terdapat interaksi antara jarak tanam legowo 2 : 1 dan dosis pupuk $\mathrm{N}$ terhadap indeks luas daun pada tanaman jagung hibrida Pertiwi 3.

Tabel 2 menunjukkan bahwa terdapat pengaruh yang berbeda dari masing-masing jarak tanam terhadap pemberian berbagai taraf dosis pupuk N. Pemberian pupuk N dengan dosis $300 \mathrm{~kg} / \mathrm{ha}$ pada jarak tanam legowo $2: 1$ $(75 \mathrm{~cm}$ X $25 \mathrm{~cm}$ X $25 \mathrm{~cm})$ menghasilkan indeks luas daun tertinggi pada tanaman jagung hibrida Pertiwi 3, sedangkan pada pemberian pupuk $\mathrm{N}$ dengan dosis $400 \mathrm{~kg} / \mathrm{ha}$ pada jarak tanam legowo $(75 \mathrm{~cm} \quad \times \quad 35 \mathrm{~cm} \quad \times \quad 35 \mathrm{~cm})$ menghasilkan indeks luas daun terendah pada tanaman jagung hibrida Pertiwi 3.

Tingginya indeks luas daun diakibatkan oleh ruang tumbuh yang rapat sehingga akan mengurangi terjadinya persaingan antar tanaman jagung serta tajuk tanaman dapat saling menaungi satu sama lain sehingga akan menutupi area luasan tanah sehingga cahaya matahari dapat diserap lebih banyak dan lebih baik oleh daun dibandingkan luasan tanah. Interaksi terbaik terdapat pada jarak tanam 75 $\mathrm{cm} \times 25 \mathrm{~cm} \times 25 \mathrm{~cm}$ dengan dosis pupuk 300 $\mathrm{kg} / \mathrm{ha}$, hal ini diakibatkan karena jarak tanam yang rapat berbanding lurus dengan dosis pupuk $\mathrm{N}$ yang lebih tinggi. Menurut Peter,et al (1992), bahwa hal-hal yang mempengaruhi besarnya indeks luas daun adalah kerapatan tanaman dan penyediaan hara terutama nitrogen.

Tabel 2. Respons Interaksi Jarak Tanam Legowo 2 : 1 dan Dosis pupuk $\mathbf{N}$ Terhadap Indeks Luas Daun pada Tanaman Jagung Hibrida Pertiwi 3.

\begin{tabular}{cccc}
\hline $\begin{array}{c}\text { Jarak Tanam } \\
\text { Legowo } \mathbf{2 ~ : 1}\end{array}$ & $\begin{array}{c}\mathbf{p}_{\mathbf{1}} \\
\mathbf{2 0 0} \mathbf{~ k g} / \mathbf{h a}\end{array}$ & $\begin{array}{c}\mathbf{p}_{\mathbf{2}} \\
\mathbf{3 0 0} \mathbf{~ k g} / \mathbf{h a}\end{array}$ & $\begin{array}{c}\mathbf{p}_{\mathbf{3}} \\
\mathbf{4 0 0} \mathbf{~ k g} / \mathbf{h a}\end{array}$ \\
\hline $\mathrm{j}_{1}(75 \times 25 \times 25 \mathrm{~cm})$ & $2,43 \mathrm{a}$ & $3,08 \mathrm{~b}$ & $2,48 \mathrm{a}$ \\
& $\mathrm{B}$ & $\mathrm{B}$ & $\mathrm{B}$ \\
$\mathrm{j}_{2}(75 \times 30 \times 30 \mathrm{~cm})$ & $1,67 \mathrm{a}$ & $1,87 \mathrm{a}$ & $2,41 \mathrm{~b}$ \\
& $\mathrm{~A}$ & $\mathrm{~A}$ & $\mathrm{~B}$ \\
$\mathrm{j}_{3}(75 \times 35 \times 35 \mathrm{~cm})$ & $1,93 \mathrm{a}$ & $2,02 \mathrm{a}$ & $1,48 \mathrm{a}$ \\
& $\mathrm{A}$ & $\mathrm{A}$ & $\mathrm{A}$ \\
\hline
\end{tabular}

Keterangan: Huruf kecil dibaca kearah vertikal pada kolom yang sama. Huruf kapital dibaca kearah horizontal pada baris yang sama. Angka yang ditandai dengan huruf yang sama.tidak berbeda nyata menurut uji jarak berganda Duncan taraf nyata $5 \%$.

Pengamatan komponen hasil panjang tongkol dan diameter tongkol disajikan pada Tabel 3. Tidak terdapat interaksi antara jarak tanam legowo 2:1 dan pupuk $\mathrm{N}$ terhadap panjang tongkol dan diameter tongkol pada tanaman jagung hibrida Pertiwi 3.

Pada Tabel 3 terlihat bahwa efek mandiri perlakuan jarak tanam legowo $2: 1$ tidak berpengaruh nyata terhadap panjang tongkol dan diameter tongkol tanaman, akan tetapi pada efek mandiri perlakuan dosis pupuk $\mathrm{N}$ terhadap panjang tongkol dan diameter tongkol terlihat bahwa hasilnya berbeda nyata antara perlakuan dosis $200 \mathrm{~kg} / \mathrm{ha}$ dengan $400 \mathrm{~kg} / \mathrm{ha}$.

Salah satu unsur yang berperan dalam perkembangan buah adalah unsur $\mathrm{N}$, apabila unsur tersebut terpenuhi maka proses perkembangan buah jagung menjadi optimal dan masak pada saatnya. Hal tersebut didukung dengan penelitian Rina (2015), bahwa apabila unsur N tercukupi maka perkembangan buah menjadi sempurna dan masak pada waktunya, dan apabila unsur $\mathrm{N}$ tidak tercukupi maka perkembangan buah menjadi tidak sempurna dan seringkali masak sebelum waktunya. 
Tabel 3. Respons Perlakuan Jarak Tanam Legowo 2 : 1 dan Pupuk N Terhadap Panjang Tongkol dan Diameter Tongkol Pada Tanaman Jagung Hibrida Pertiwi 3

\begin{tabular}{lcc}
\hline \multicolumn{1}{c}{ Perlakuan } & $\begin{array}{c}\text { Panjang } \\
\text { Tongkol }(\mathbf{c m})\end{array}$ & $\begin{array}{c}\text { Diameter } \\
\text { Tongkol }(\mathbf{c m})\end{array}$ \\
\hline \multicolumn{3}{l}{ Jarak Tanam Legowo $2: \mathbf{1}$} \\
$\mathrm{j}_{1}(75 \times 25 \times 25 \mathrm{~cm})$ & $14,16 \mathrm{a}$ & $5,05 \mathrm{a}$ \\
$\mathrm{j}_{2}(75 \times 30 \times 30 \mathrm{~cm})$ & $13,75 \mathrm{a}$ & $4,97 \mathrm{a}$ \\
$\mathrm{j}_{3}(75 \times 35 \times 35 \mathrm{~cm})$ & $14,56 \mathrm{a}$ & $5,12 \mathrm{a}$ \\
\hline Pupuk N & $13,53 \mathrm{a}$ & $4,88 \mathrm{a}$ \\
$\mathrm{p}_{1} 200 \mathrm{~kg} / \mathrm{ha}$ & $14,07 \mathrm{a}$ & $5,10 \mathrm{ab}$ \\
$\mathrm{p}_{2} 300 \mathrm{~kg} / \mathrm{ha}$ & $14,87 \mathrm{a}$ & $5,16 \mathrm{~b}$ \\
$\mathrm{p}_{3} 400 \mathrm{~kg} / \mathrm{ha}$ &
\end{tabular}

Keterangan : Angka rata-rata pada tiap kolom yang di tandai huruf yang sama menunjukkan tidak berbeda nyata menurut uji Jarak Berganda Duncan Taraf 5 \%.

Tabel 4. Respons Perlakuan Jarak Tanam Legowo 2 : 1 dan Pupuk $\mathbf{N}$ terhadap Jumlah Baris Biji Per Tongkol dan Jumlah Biji Per Tanaman Pada Tanaman Jagung Hibrida Pertiwi 3.

\begin{tabular}{lcc}
\hline \multicolumn{1}{c}{ Perlakuan } & $\begin{array}{c}\text { Jumlah Baris } \\
\text { Biji Per } \\
\text { Tongkol }\end{array}$ & $\begin{array}{c}\text { Jumlah Biji } \\
\text { Per Tanaman }\end{array}$ \\
\hline Jarak Tanam Legowo 2 : 1 \\
$\mathrm{j}_{1}(75 \times 25 \times 25 \mathrm{~cm})$ & $13,33 \mathrm{a}$ & $489,48 \mathrm{a}$ \\
$\mathrm{j}_{2}(75 \times 30 \times 30 \mathrm{~cm})$ & $14.84 \mathrm{a}$ & $431,11 \mathrm{a}$ \\
$\mathrm{j}_{3}(75 \times 35 \times 35 \mathrm{~cm})$ & $13,66 \mathrm{a}$ & $488,85 \mathrm{a}$ \\
\hline Pupuk N & $13,33 \mathrm{a}$ & $438,00 \mathrm{a}$ \\
$\mathrm{p}_{1} 200 \mathrm{~kg} / \mathrm{ha}$ & $13,57 \mathrm{a}$ & $474,40 \mathrm{a}$ \\
$\mathrm{p}_{2} 300 \mathrm{~kg} / \mathrm{ha}$ & $14,93 \mathrm{a}$ & $497,03 \mathrm{a}$ \\
$\mathrm{p}_{3} 400 \mathrm{~kg} / \mathrm{ha}$ &
\end{tabular}

Keterangan : Angka rata-rata pada tiap kolom yang di tandai huruf yang sama menunjukan tidak berbeda nyata menurut uji Jarak Berganda Duncan Taraf $5 \%$.

Pengamatan komponen jumlah baris biji dan jumlah biji per tanaman disajikan pada Tabel 4. Tidak terdapat interaksi antara jarak tanam legowo 2:1 dan pupuk $\mathrm{N}$ terhadap jumlah baris biji per tongkol dan jumlah biji per tanaman.

Pada Tabel 4 terlihat efek mandiri perlakuan jarak tanam legowo 2 : 1 tidak berpengaruh nyata terhadap jumlah baris biji dan jumlah biji per tongkol begitu juga dengan efek mandiri perlakuan dosis pupuk $\mathrm{N}$ terhadap jumlah baris biji dan jumlah biji per tongkol terlihat bahwa hasilnya tidak berbeda nyata. Menurut deskripsi jagung hibrida Pertiwi 3 yang bersumber dari Kementrian Pertanian (2013), jumlah baris biji pada tanaman jagung hibrida Pertiwi 3 berkisar antara 14-16. Pada penelitian aplikasi jarak tanam legowo 2:1 dan dosis pupuk
$\mathrm{N}$ ini memperoleh hasi rata-rata jumlah baris biji sekitar 13-14 baris yang mana sudah sesuai dengan deskripsi jagung hibrida Pertiwi 3.

Pengamatan hasil bobot biji pipilan kering per tanaman dan bobot 100 biji disajikan pada Tabel 5. Tidak terdapat interaksi antara jarak tanam legowo 2:1 dan pupuk $\mathrm{N}$ terhadap bobot pipilan kering per tanaman dan bobot 100 biji.

Tabel 5. Respons Perlakuan Jarak Tanam Legowo 2 : 1 dan Pupuk N Terhadap BobotPipilan Kering Per Tanaman dan Bobot 100 Biji Pada Tanaman Jagung Hibrida Pertiwi 3.

\begin{tabular}{lcc}
\hline \multicolumn{1}{c}{ Perlakuan } & $\begin{array}{c}\text { Bobot Pipilan } \\
\text { Kering Per } \\
\text { Tanaman }(g)\end{array}$ & $\begin{array}{c}\text { Bobot 100 } \\
\text { biji }(g)\end{array}$ \\
\hline Jarak Tanam Legowo $2: \mathbf{1}$ \\
$\mathrm{j}_{1}(75 \times 25 \times 25 \mathrm{~cm})$ & $146,00 \mathrm{ab}$ & $29,80 \mathrm{a}$ \\
$\mathrm{j}_{2}(75 \times 30 \times 30 \mathrm{~cm})$ & $129,68 \mathrm{a}$ & $30,02 \mathrm{a}$ \\
$\mathrm{j}_{3}(75 \times 35 \times 35 \mathrm{~cm})$ & $154,59 \mathrm{~b}$ & $31,48 \mathrm{a}$ \\
\hline Pupuk N & $130,14 \mathrm{a}$ & $29,55 \mathrm{a}$ \\
$\mathrm{p}_{1} 200 \mathrm{~kg} / \mathrm{ha}$ & $146,24 \mathrm{a}$ & $30,36 \mathrm{a}$ \\
$\mathrm{p}_{2} 300 \mathrm{~kg} / \mathrm{ha}$ & $153,89 \mathrm{a}$ & $31,39 \mathrm{a}$ \\
$\mathrm{p}_{3} 400 \mathrm{~kg} / \mathrm{ha}$ &
\end{tabular}

Keterangan :Angka rata-rata pada tiap kolom yang di tandai huruf yang sama menunjukkan tidak berbeda nyata menurut uji Jarak Berganda Duncan Taraf $5 \%$.

Jarak tanam yang lebih sempit mampu meningkatkan produksi per luas lahan dan jumlah biji namun menurukan bobot dari biji (Maddonni $d k k$, 2006), hal tersebut sejalan dengan hasil yang di dapat pada penelitian ini yaitu pada perlakuan dengan jarak tanam $75 \mathrm{~cm}$ x $35 \mathrm{~cm}$ x $35 \mathrm{~cm}$ yang memberikan hasil pipilan kering pertanaman dan bobot 100 biji tertinggi yaitu 154,59 gram dan 31,48 gram. Hasil bobot 100 biji pada penelitian ini sesuai dengan deskripsi jagung hibrida Pertiwi 3 yang dikeluarkan oleh Kementrian Pertanian, 2013yang menyatakan bahwa bobot 100 biji yang di dapat $+30 \mathrm{~g}$ dan hasil tertinggi yang di dapat pada penelitian ini yaitu $31,48 \mathrm{~g}$.

Pengamatan hasil bobot biji per petak dan bobot biji per hektar disajikan pada Tabel 6, tidak terdapat interaksi antara jarak tanam legowo 2:1 dan pupuk $\mathrm{N}$ terhadap bobot biji per petak dan bobot bobot biji per hektar pada tanaman jagung hibrida Pertiwi 3.

Pemberian perlakuan jarak tanam legowo 2 : 1 mampu memberikan perbedaan yang nyata, terbukti bahwa pada perlakuan jarak tanam 75 $\mathrm{cm} \times 25 \mathrm{~cm} \times 25 \mathrm{~cm}$ memberikan hasil tertinggi dan memberikan hasil terbaik terhadap bobot biji per petak dan bobot biji per ha dibandingkan 
dengan jarak tanam yang lebih besar yaitu $75 \mathrm{~cm}$ x $30 \mathrm{~cm} \times 30 \mathrm{~cm}$ dan $75 \mathrm{~cm} \times 35 \mathrm{~cm} \times 35 \mathrm{~cm}$. Hal ini disebabkan karena penanaman dengan jarak tanam lebar diperoleh populasi lebih sedikit dibandingkan dengan jarak tanam yang lebih rapat sehingga hasil yang didapatkan cenderung lebih sedikit.

Tabel 6. Respons Perlakuan Jarak Tanam Legowo 2 : 1 dan Pupuk N Terhadap Bobot Biji Per Petak dan Bobot Biji Per Hektar Pada Tanaman Jagung Hibrida Pertiwi 3.

\begin{tabular}{|c|c|c|}
\hline \multirow[t]{2}{*}{ Perlakuan } & \multicolumn{2}{|c|}{ Bobot Biji Per Bobot Biji Per } \\
\hline & Petak (g) & Hektar (ton) \\
\hline \multicolumn{3}{|c|}{ Jarak Tanam Legowo 2 : 1} \\
\hline $\mathrm{j}_{1}(75 \times 25 \times 25 \mathrm{~cm})$ & $12264,00 \mathrm{~b}$ & $11,68 \mathrm{~b}$ \\
\hline $\mathrm{j}_{2}(75 \times 30 \times 30 \mathrm{~cm})$ & 9516,06 a & 8,23 a \\
\hline $\mathrm{j}_{3}(75 \times 35 \times 35 \mathrm{~cm})$ & 9292,95 a & 8,03 a \\
\hline \multicolumn{3}{|l|}{ Pupuk N } \\
\hline $\mathrm{p}_{1} 200 \mathrm{~kg} / \mathrm{ha}$ & 9736,41 a & 8,46 a \\
\hline $\mathrm{p}_{2} 300 \mathrm{~kg} / \mathrm{ha}$ & 10300,33 a & $9,43 \mathrm{ab}$ \\
\hline $\mathrm{p}_{3} 400 \mathrm{~kg} / \mathrm{ha}$ & $11036,27 \mathrm{a}$ & $10,05 \mathrm{~b}$ \\
\hline
\end{tabular}

Keterangan : Angka rata-rata pada tiap kolom yang di tandai huruf yang sama menunjukkan tidak berbeda nyata menurut uji Jarak Berganda Duncan Taraf 5 \%.

Maddonni dkk, (2006) mengatakan bahwa jarak tanam yang sempit dapat meningkatkan produksi yang lebih besar. Menurut Waxn and Stoller (1987), pada dasarnya pengaplikasian jarak tanam yang rapat bertujuan untuk meningkatkan hasil, dengan syarat faktor pembatas dapat dihindari sehingga tidak terjadi persaingan antar tanaman satu sama lain. Efek mandiri pemberian pupuk $\mathrm{N}$ mampu meningkatkan hasil dari tanaman. Menurut Suratmini (2009) dengan pemupukan N kurang dari $300 \mathrm{~kg} / \mathrm{ha}$ hasil lebih rendah jika dibandingkan dengan pemupukan N $400 \mathrm{~kg} / \mathrm{ha}$. Hal ini sejalan dengan penelitian Saragih $d k k$, (2013) yang menjelaskan bahwa tanaman jagung mengambil $\mathrm{N}$ sepanjang hidupnya.

Pengamatan hasil indek panen disajikan pada Tabel 7. Tidak terdapat interaksi antara jarak tanam legowo 2:1 dan pupuk $\mathrm{N}$ terhadap indeks panen pada tanaman jagung hibrida Pertiwi 3.

Pada Tabel 7 terlihat respons mandiri perlakuan jarak tanam legowo 2 : 1 tidak berpengaruh nyata terhadap indeks panen begitu juga dengan respons mandiri perlakuan dosis pupuk $\mathrm{N}$ terhadap indeks panen tanaman jagung hibrida Pertiwi 3. Indeks panen merupakan rasio dari bobot kering yang bernilai ekonomi (biji) dengan hasil bobot kering total tanaman. Hasil penelitian dari Balai Penelitian Tanaman Pangan Bogor, indeks panen pada tanaman jagung di daerah tropis sekitar 0,39, begitu juga menurut Indradewa, $d k k$ (2005) bahwa indeks panen jagung berada di sekitar angka 0,39.Pada penelitian ini, indeks panen berkisar antara 0,38-0,41. Faktor lain yang mempengaruhi yaitu jarak tanam yang lebar karena mempengaruhi penyerapan sinar matahari dan fotosintesis berjalan optimal yang berdampak pada hasil fotosintat untuk pengisian biji.

Tabel 7. Respons Perlakuan Jarak Tanam Legowo 2 : 1 dan Pupuk N Terhadap Indeks Panen Pada Tanaman Jagung Hibrida Pertiwi 3.

\begin{tabular}{lc}
\hline \multicolumn{1}{c}{ Perlakuan } & Indeks Panen \\
\hline Jarak Tanam Legowo 2 : & \\
$\mathrm{j}_{1}(75 \times 25 \times 25 \mathrm{~cm})$ & $0.39 \mathrm{a}$ \\
$\mathrm{j}_{2}(75 \times 30 \times 30 \mathrm{~cm})$ & $0.38 \mathrm{a}$ \\
$\mathrm{j}_{3}(75 \times 35 \times 35 \mathrm{~cm})$ & $0.41 \mathrm{a}$ \\
\hline Pupuk N & $0,38 \mathrm{a}$ \\
$\mathrm{p}_{1} 200 \mathrm{~kg} / \mathrm{ha}$ & $0,39 \mathrm{a}$ \\
$\mathrm{p}_{2} 300 \mathrm{~kg} / \mathrm{ha}$ & $0,40 \mathrm{a}$ \\
$\mathrm{p}_{3} 400 \mathrm{~kg} / \mathrm{ha}$ & \\
\hline
\end{tabular}

Keterangan : Angka rata-rata pada tiap kolom yang ditandai huruf yang sama menunjukkan tidak berbeda nyata menurut uji Jarak Berganda Duncan Taraf $5 \%$.

\section{Kesimpulan}

Terdapat pengaruh interaksi antara jarak tanam legowo 2 : 1 dengan pemberian pupuk $\mathrm{N}$ terhadap Indeks Luas Daun tanaman jagung. Secara mandiri jarak tanam legowo $2: 1$ memberikan hasil terbaik yaitu pada jarak tanam $75 \mathrm{~cm} \times 25 \mathrm{~cm} \times 25 \mathrm{~cm}$ dengan hasil $12264.00 \mathrm{~g} /$ petak atau 11,68 ton/ha, serta dosis pupuk N $400 \mathrm{~kg} / \mathrm{ha}$ dengan hasil 11036.27 $\mathrm{g} /$ petak atau 10.05 ton/ha.

\section{Daftar Pustaka}

Badan Ketahanan Pangan Kementrian Pertanian. 2015. Data Statistik Ketahanan Pangan 2014. Diakses melalui bkp.pertanian.go.id/ Pada 09/03/2017 21.05.

Ikhwani, G.R. Pratiwi, E. Paturrohman dan A.K. Makarim. 2013. Peningkatan Produktivitas Padi Melalui Penerapan Jarak Tanam Jajar Legowo. Puslitbang Tan. Pangan. Bogor. 
Indradewa D, Kastono D, S. Yasmin. 2005. Kemungkinan Peningkatan Hasil Jagung Dengan Pemendekan Batang. Ilmu Pertanian. Vol. 12 No.2 Hal . 117-124.

Kasno, A. 2010. Respon pemupukan N dan P Untuk Tanaman Jagung. J. Agroteknologi, 13-22.

Kementrian Perindustrian. 2016. Kebutuhan Jagung di Indonesia. Diakses melalui http:/ / www.kemenperin.go.id Pada 5 Mei 2017.

Kementrian Pertanian. 2013. Tumpangsari Jagung Dengan Kedelai Dalam Sistem Tanam Legowo. http://www.pertanian.go. id/ap_posts/detil/384/2015/06/23/08/55 /19/\%20Tumpangsari\%20Jagung\%20deng an\%20Kedelai \%20dalam \%20Sistem\%20Tan am_Diakses pada : 10 Oktober 2016).

Kementrian Pertanian. 2016. Varietas Jagung Hibrida Pertiwi 3. Diakses melalui www. pertanian.go.id Pada 10/03/2017 20.29.

MaddoniGA, Cirilo and Otegui ME. 2006. Row Widht and Maize Grainyield. Agron. J.98:1532-1543.

Monsanto Company, 2013. Effects of Twin Row Configuration on Corn Yield. Monsanto Co. 1-2.

Oldeman, L.R., 1975. Agroclimatic map of Java \& Madura. Contr. of Centra Res. Inst. for Food Crops 16/76. Bogor.

Peter R. Goldsworthy dan N.M. Fisher. 1992. Fisiologi Tanaman Budidaya (Terjemah dari The Phsiology of Tropical Field Crops oleh Tohari). Gadjah Mada University Press. Yogyakarta.
Rina 2015. Pertumbuhan dan Hasil Tanaman Jagung (Zea mays L.) Yang Ditumpangsarikan Dengan Kedelai (Glycine max L.). Fakultas Pertanian Jurusan Agroteknologi Universitas Tamansiswa, Padang.

Saragih, D., Hamim, H., Nurmauli, N., 2013. Meningkatkan Pertumbuhan dan Hasil Jagung (Zea mays , L .) Pioneer 27 1, 50-54.

Setyamidjadja, D. 1986. Pupuk dan Pemupukan. Bandung: CV. Simplek.

Sinartani, 2011. Jagung Hibrida Unggul Nasional. AGROINOVASI 4-6.

Stalcup, L. 2008. Twin Rows Help Boost Yields: Stil, The Jury's Out on Whether Twin Rows are Always Profitable. Corn and Soybean Digest; Jan 2008; 68,1; ABI/Inform Trade and Industry. Page. 6.

Suratmini, P. 2009. Kombinasi Pemupukan Urea dan Pupuk Organik pada Jagung Manis di Lahan Kering. Penelitian Tanaman Pangan. Vol. 28 No. 2

Tuherkih, E. Sipahutar, I.A. 2008. Pengaruh Pupuk NPK Majemuk (16:16:15) Terhadap Pertumbuhan dan Hasil Jagung (Zea Mays L) Di Tanah Inceptisols. Balai Penelitian. Tanah 77-88.

Wax M. Stoller EW. 1987. Aspects of weed cropsinterference related to weed control practice.World Soybean Research Conference III.Westview. London. pp. 116124.

Yasin, M., Suarni, 2011. Jagung sebagai sumber pangan fungsional. Iptek Tanam. Pangan 6, 41-56. 